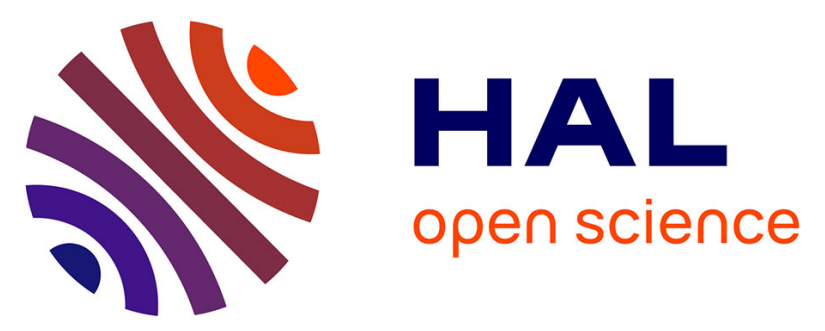

\title{
Fe(IV) Disproportionation in AFeO3 (A = Ca, Sr) Perovskite Lattices Studied by 119Sn Diamagnetic Probe Mössbauer Spectroscopy
}

Léopold Fournès, Gérard Demazeau, Stéphane Darracq, Jean Etourneau, P. Fabritchnyi, I. A. Presniakov, K. V. Pokholok, V. P. Gorkov

\section{To cite this version:}

Léopold Fournès, Gérard Demazeau, Stéphane Darracq, Jean Etourneau, P. Fabritchnyi, et al.. Fe(IV) Disproportionation in AFeO3 (A = Ca, Sr) Perovskite Lattices Studied by 119Sn Diamagnetic Probe Mössbauer Spectroscopy. Journal de Physique IV Proceedings, 1997, 07 (C1), pp.C1-363-C1-364. 10.1051/jp4:19971148 . jpa-00254792

\section{HAL Id: jpa-00254792 https://hal.science/jpa-00254792}

Submitted on 1 Jan 1997

HAL is a multi-disciplinary open access archive for the deposit and dissemination of scientific research documents, whether they are published or not. The documents may come from teaching and research institutions in France or abroad, or from public or private research centers.
L'archive ouverte pluridisciplinaire HAL, est destinée au dépôt et à la diffusion de documents scientifiques de niveau recherche, publiés ou non, émanant des établissements d'enseignement et de recherche français ou étrangers, des laboratoires publics ou privés. 


\title{
$\mathrm{Fe}(\mathrm{IV})$ Disproportionation in $\mathrm{AFeO}_{3}(\mathrm{~A}=\mathrm{Ca}, \mathrm{Sr})$ Perovskite Lattices Studied by ${ }^{119}$ Sn Diamagnetic Probe Mössbauer Spectroscopy
}

\author{
L. Fournès, G. Demazeau, S. Darracq, J. Etourneau, P. Fabritchnyi*, I.A. Presniakov*, K.V. Pokholok* \\ and V.P. Gorkov*
}

Institut de Chimie de la Matière Condensée de Bordeaux, avenue du Dr. A. Schweitzer, 33608 Pessac cedex, France

* Chaire de Radiochimie, Faculté de Chimie, Université Lomonosov, I19889 Moscou V-234, Russia

\begin{abstract}
Fe(IV) is an interesting unusual oxidation state of iron stabilized under oxygen pressure. In a perovskite lattice sucl an oxidation state disporportionates into $\mathrm{Fe}(\mathrm{HI})$ and $\mathrm{Fo}(\mathrm{V})$. The study of this phemomenon is important for a better kiowledge of instable valencies. Using ${ }^{119} \mathrm{Sn}(\mathrm{IV})$ as diamagnetic probe in the perovskite lattice of $\mathrm{AFeO}_{3}(\mathrm{~A}=\mathrm{Ca}, \mathrm{Sr})$ the disproportionation $2 \mathrm{Fe}(\mathrm{IV}) \underset{\mathrm{Fe}}{\rightleftarrows}(\mathrm{III})+\mathrm{Fe}(\mathrm{V})$ is discussed versus locil steric and electrostatic interactions.
\end{abstract}

\section{INTRODUCTION}

The formal $\mathrm{Fe}(\mathrm{IV})$ oxidation state has been stabilized in differcnt oxygen lattices derived from perovskite or $\mathrm{K}_{2} \mathrm{NiF}_{4}$ structures using oxygen pressures [1]. In the $\left(\mathrm{AA}^{\prime}\right)_{2} \mathrm{M}_{0.50} \mathrm{Fe}(\mathrm{IV})_{0.50} \mathrm{O}_{4}\left(\mathrm{~A}=\mathrm{La}, \mathrm{A}^{\prime}=\mathrm{Ca}\right.$.Sr.Ba, $\left.\mathrm{M}=\mathrm{Li} . \mathrm{Mg}, \mathrm{Zn}\right)$ the high spin state $\left(t_{2 \mathrm{~g}}^{3} \mathrm{~d}_{\mathrm{z}^{2}}\right)$ is mainly observed with a local Jahn-Teller distortion [2]. In the antiferromagnetic perovskite $\mathrm{CaFcO}_{3}$, the disproportionation $[2 \mathrm{Fe}(\mathrm{IV}) \rightarrow \mathrm{Fe}(\mathrm{III})+\mathrm{Fe}(\mathrm{V})]$ was detected at $280 \mathrm{~K}$ using ${ }^{57} \mathrm{Fe}$ Mössbauer spectroscopy [3]. This phenomenon is not observed in $\mathrm{SrFeO}_{3}$ characterized by a metallic behaviour [4] confirmed recently by theoritical calculations [5]. The purpose of this study was to evaluate in both oxides the role of the local electronic phenomenon on the $\mathrm{Fe}(\mathrm{IV})$ disproportionation. ${ }^{119} \mathrm{~S}$ n was used as diamagnetic Mössbauer probe. the magnetic fields observed by ${ }^{119} \mathrm{~S} n$ being dependent on the electronic configurations of neighbouring ions.

\section{PREPARATION OF THE Sn-DOPEd $\mathrm{AFeO}_{3}$ PEROVSKITE $(\mathrm{A}=\mathrm{Ca}, \mathrm{Sr})$}

These materials were prepared through a thermal treatment of a stoichiometric mixture of calcium or strontium nitrate for carbonate) and iron hydroxide containing few amounts of Sn. In order to prevent strong modifications of the properties of the perovskite matrix. the doping level is small $\left(0.5 \%\right.$ at. Sn for $\mathrm{CaFeO}_{3}$ and $1 \%$ at. $\mathrm{Sn}$ for $\mathrm{SrFeO}_{3}$ enriched at $92 \%$ in $\left.{ }^{11}{ }^{\mathrm{S} n}\right)$.

\section{MÖSSBAUER INVESTIGATIONS}

$3.1 \mathrm{SrFeO}_{3}: 1 \%$ at. $\mathrm{Sn}$

At $293 \mathrm{~K}$, two different absorptions are observed on the ${ }^{57} \mathrm{Fe}$ Mössbauer spcctrum attributed respectively to $\mathrm{Fe}(\mathrm{IV})(88 \%)-\delta /($ $\alpha-\mathrm{Fe})=0.057 \mathrm{~mm} \cdot \mathrm{s}^{-1}, \Gamma=0.47 \mathrm{~mm} . \mathrm{s}^{-1}$, and $\mathrm{Fe}(\mathrm{III})(12 \%)-\delta /(\alpha-\mathrm{Fe})=0.27 \mathrm{~mm} . \mathrm{s}^{-1} . \Gamma=0.30 \mathrm{~mm} \cdot \mathrm{s}^{-1}$. The deduced stoichiometry is $\mathrm{SrFeO}_{2.94}$. At the same temperature, the ${ }^{119} \mathrm{Sn}$ spectrum corresponds 10 a singlet $\left(8 / \mathrm{CaSnO}_{3}=0.11 \mathrm{~mm} . \mathrm{s}^{-1}\right.$. $\Gamma=0.88 \mathrm{~mm} . \mathrm{s}^{-1}$ ) characterizing $\mathrm{Sn}(\mathrm{IV})$ in oxides [6]. At $+.2 \mathrm{~K}$. due to the antiferromagnetic ordering of $\mathrm{SrFeO}_{3}$, the spin polarization of Sn(IV) induces a large diffuse absorption (Fig. 1) attributed to a large distribution of hyperfine fields. Such a distribution was analyzed through the Hesse and Rubartsch's model considering a constant value for $\delta$ and $\Delta$ equal 0 [7]. The resulting $p(H)=f(H)$ diagram (Fig. 2) is symmetrical versus the average $\overline{\mathrm{H}}$ value $(220 \mathrm{kOe})$. This diagram was analyzed [9] in terms of a statistical distribution of $\mathrm{Fe}(\mathrm{III})\left(\mathrm{t}_{2 \mathrm{~g}}^{3} \mathrm{e}_{\mathrm{g}}^{2}\right)\left[\mathrm{Sn}(\overline{\mathrm{H}})=270 \mathrm{kOe}[8]\right.$ and $\mathrm{Fe}(\mathrm{V})\left(\mathrm{t}_{2 \mathrm{~g}}^{3} \mathrm{e}_{\mathrm{g}}^{0}\right)[\mathrm{Sn}(\overline{\mathrm{H}})=30 \mathrm{kOe}$ for $\mathrm{Cr}(\mathrm{III})][10]$. 


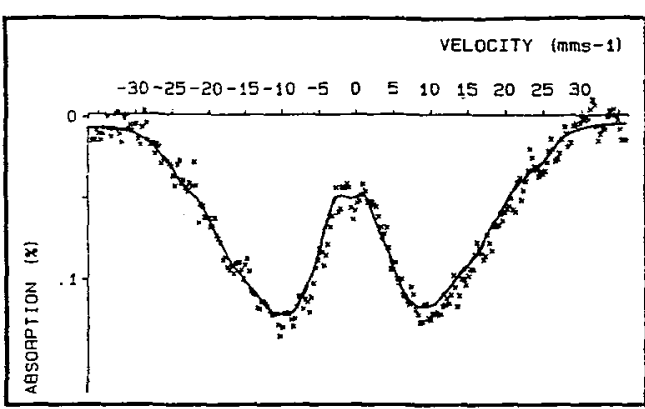

Fig. l: Mössbater spectrum at $4.2 \mathrm{~K}_{\text {of }} \mathrm{SrFeO}_{3} \cdot 1 \% \mathrm{Sn}$

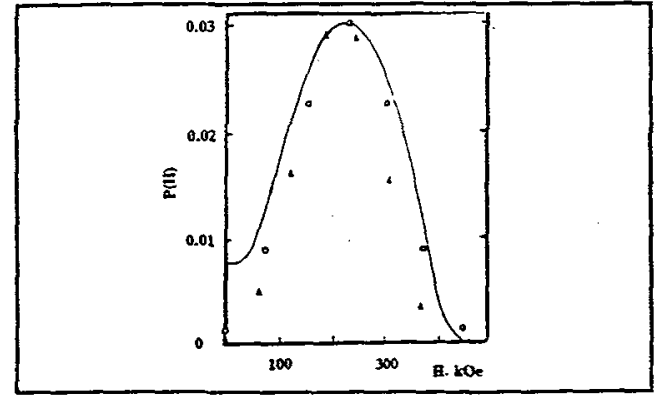

Fig. 2: ${ }^{119} \mathrm{Sn}$ bypertine field distribution $\mathrm{P}(\mathrm{H})=\mathrm{t}(\mathrm{H})$ tor $\mathrm{SrFeO}_{3}: 1 \% \mathrm{Sn}$

\section{2 $\mathrm{CaFeO}_{3}: 0.5 \%$ at.Sn}

The ${ }^{119} \mathrm{Sn}$ Mössbauer spectrum is given on figure 3. Using the same analysis than that developed for $\mathrm{SrFeO}_{3}: 1 \%$ at.Sn. a different hyperfine fields distribution is observed (Fig. 4 ) corresponding respectively to $6 \mathrm{Fe}(\mathrm{V})$ and $5 \mathrm{Fe}(\mathrm{V})+1 \mathrm{Fe}(\mathrm{III})$ in the near $\mathrm{Sn}$ surrounding [9]. Such a behaviour was attributed to steric effects inducing preferentially small cations in the first Sn(IV) coordination.

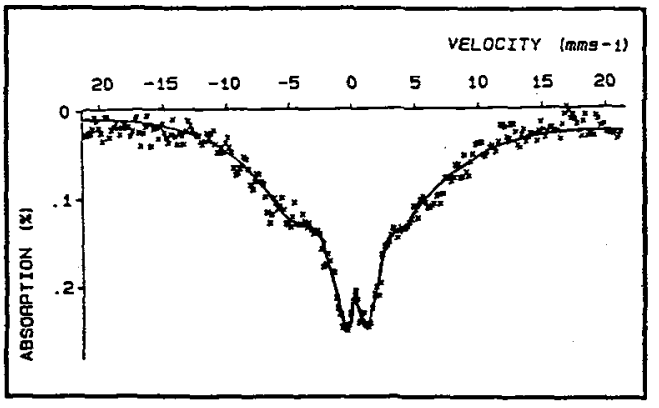

Fig. 3: Mössbauer spectrum at $4.2 \mathrm{~K}_{\text {of }} \mathrm{CaFeO}_{3}: 0,5 \% \mathrm{Sn}$

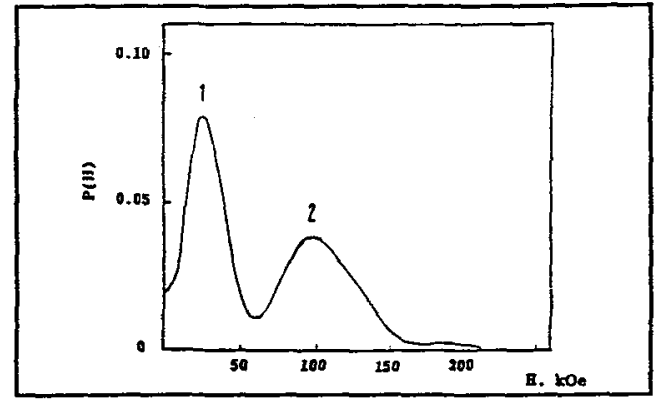

Fig. $4:{ }^{119}$ Sn hypertine tield distribution $\mathrm{P}(\mathrm{H})=\mathrm{t}(\mathrm{H})$ tor $\mathrm{CaFeO}_{3}: 0.5 \% \mathrm{Sn}$

\section{CONCLUSIONS}

The use of $\mathrm{Sn}$ dianagnetic probe induces, in the $\mathrm{SrFeO}_{3}$ lattice. the $\mathrm{Fe}(\mathrm{IV})$ disproportionation in the $\mathrm{Sn}$ vicinity due to a local slowering of the electronic delocalization. The $\mathrm{Fe}(\mathrm{III}) \mathrm{Fe}(\mathrm{V})$ distribution seems closely dependent on steric effects $\cdot\left(\mathrm{a}_{\mathrm{CaFeO}}<\mathrm{a}_{\mathrm{SrFeO}_{3}}\right)$.

\section{References}

[1] Demazeau G., High Pressure Chemical Synthesis. Ed. J. Jurczack and B. Baranowski. chap. 5, pp. 101-133.

[2] Demazeau G., Chevreau N., Fournès L., Soubeyroux J.L.. Thomas M. and Pouchard M., Rev. Chim. Mineral, 20 (1993) 155-172.

[3] Takano M., Nasu S., Abe T.. Yamamoto K. Endo S. Takeda Y. and Goodenough J.B.. Phis. Rev. Lett. 67 (1991) $3267-$ 3270.

[4] Takano M., Nakanishi N. Takeda Y., Naka S. and Takeda T.. Mater. Res. Bull.. 12 (1977) 923-928.

[5] Matar S., Demazeau G., Mohn P., Eyert V. and Najm S.. Europ. J. of Solid State and Inorg. (hem. 31 (1994) 615-629.

[6] Fabritchnyi P.B. and Fefilatiev L.P., Solid State Commum.. 28 (1978) 513-515.

[7] Hesse J. and Rubansch A., J. Phys. E., 7 (1974) 529.

[8] Lyubutin I.S. and Vishniakov Y.S.. Zh. Eksp. Teor. Fiz. 61 (1971) 1962.

[9] Demazeau G., Fabritchnyi P.. Fournès L., Darraca S.. Presniakov I.A.. Pokholok K. V.. Gorkov V.P. and Elourneau J.. J. Mater. Chem., 5(t) (1995) 553-556.

[10] Bokov V.A., Popov G.V., Parfenova N.N. and Yushin G.G., Fiz. Tuerd. Tela. 14 (1972) 104. 